\title{
Fighting the novel coronavirus: the publication of the Chinese expert consensus on the perinatal and neonatal management for the prevention and control of the 2019 novel coronavirus infection (First edition)
}

\author{
Editorial Office \\ AME Publishing Company \\ Correspondence to: Editorial Office. AME Publishing Company. Email: apm@amepc.org.
}

Submitted Feb 07, 2020. Accepted for publication Feb 27, 2020.

doi: 10.21037/apm.2020.02.02

View this article at: http://dx.doi.org/10.21037/apm.2020.02.02

Since December 2019, there has been an outbreak of novel coronavirus (2019-nCoV) infection in China, the first case of which was reported in Wuhan, China. On January 19, 2020, the relevant experts and local government officials briefed the public on the 2019-nCoV outbreak. Relevant information is available at: http://jphe.amegroups.com/ announcement/view/179.

By February 5, 2020, two cases of neonates with positive 2019-nCoV tests had been confirmed.

In response to neonate susceptibility to $2019-\mathrm{nCoV}$, the Chinese Neonatal 2019-nCoV Expert Working Group has rapidly put forward measures for the prevention and control of neonatal 2019-nCoV according to the latest 2019-nCoV national management plan and the actual situation.

On February 6, 2020, the "Chinese expert consensus on the perinatal and neonatal management for the prevention and control of the 2019 novel coronavirus infection (First edition)", authored by the Chinese Neonatal 2019-nCoV Expert Working Group, was first published online in Annals of Translational Medicine (1).

The above consensus was reached based upon the historical literature of coronavirus infection and the most current 2019-nCoV infection data that could be acquired. The recommendations in the consensus are in accordance with "The guidelines for the diagnosis and management plan for pneumonia with new coronavirus infection (trial version 4" (2), "Technical guidelines for prevention and control of the new coronavirus infection in medical institutions", "The guidelines on the scope of use of common medical protection against new coronavirus infection" (trial), and the latest World Health Organization (WHO) principles for the treatment of $2019-\mathrm{nCoV}$ infection (3).

Meanwhile, the outbreak also drew attention and concern from the international community. Dr. Giuseppe Lippi from University Hospital of Verona shared his perspective on this infection, and his editorial commentary titled "Which lessons shall we learn from the 2019 novel coronavirus outbreak?" was published in Annals of Translational Medicine (4).

AME will keep a close eye on the epidemic and continue to publish related articles via our journal platform, delivering the most up-to-date information to all health professionals and readers.

\section{Acknowledgments}

Funding: None.

\section{Footnote}

Provenance and Peer Review: This article was commissioned by the Editorial Office, Annals of Palliative Medicine. The article did not undergo external peer review.

Conflicts of Interest: The authors have no conflicts of interest to declare.

Open Access Statement: This is an Open Access article distributed in accordance with the Creative Commons 
Attribution-NonCommercial-NoDerivs 4.0 International License (CC BY-NC-ND 4.0), which permits the noncommercial replication and distribution of the article with the strict proviso that no changes or edits are made and the original work is properly cited (including links to both the formal publication through the relevant DOI and the license). See: https://creativecommons.org/licenses/by-nc-nd/4.0/.

\section{References}

1. Wang L, Shi Y, Xiao T, et al. Chinese expert consensus on the perinatal and neonatal management for the prevention and control of the 2019 novel coronavirus infection

Cite this article as: Editorial Office. Fighting the novel coronavirus: the publication of the Chinese expert consensus on the perinatal and neonatal management for the prevention and control of the 2019 novel coronavirus infection (First edition). Ann Palliat Med 2020;9(2):524-525. doi: 10.21037/ apm.2020.02.02
(First edition). Ann Transl Med 2020. doi: 10.21037/ atm.2020.02.20

2. Diagnosis and management plan of pneumonia with new coronavirus infection (trial version 4). Beijing: National Health and Health Commission, 2020.

3. World Health Organization. Interim clinical guidance for management of patients with confirmed 2019 novel coronavirus (2019-nCoV) Infection. Available online: https://www.cdc.gov/coronavirus/2019-ncov/hcp/clinicalguidance-management-patients.html

4. Mattiuzzi C, Lippi G. Which lessons shall we learn from the 2019 novel coronavirus outbreak? Ann Transl Med 2020. doi: $10.21037 / \mathrm{atm} .2020 .02 .06$. 